\title{
The Usefulness of Elemental Iron for Cereal Flour Fortification: A SUSTAIN Task Force Report
}

\author{
Richard Hurrell, Ph.D., Thomas Bothwell, M.D., James D. Cook, M.D., Omar Dary, Ph.D., \\ Lena Davidsson, Dr. Med.Sc., Susan Fairweather-Tait, Ph.D., Leif Hallberg, M.D., \\ Sean Lynch, M.D., Jorge Rosado, Ph.D., Tomas Walter, M.D., and Paul Whittaker, Ph.D.
}

\begin{abstract}
Fortification of cereal flours may be a useful public health strategy to combat iron deficiency. Cereal flours that are used shortly after production (e.g., baking flour) can be fortified with soluble iron compounds, such as ferrous sulfate, whereas the majority of flours stored for longer periods is usually fortified with elemental iron powders to avoid unacceptable sensory changes. Elemental iron powders are less well absorbed than soluble iron compounds and they vary widely in their absorption depending on manufacturing method and physicochemical characteristics. Costs vary with powder type, but elemental iron powders are generally less expensive than ferrous sulfate. This review evaluates the usefulness of the different elemental iron powders based on results from in vitro studies, rat assays, human bioavailability studies, and efficacy studies monitoring iron status in human subjects. It concludes that, at the present time, only electrolytic iron powder can be recommended as an iron fortificant. Because it is only approximately half as well absorbed as ferrous sulfate, it should be added to provide double the amount of iron.
\end{abstract}

Key Words: elemental iron, iron bioavailability, cereal fortification, wheat flour fortification

(c) 2002 International Life Sciences Institute

Drs. Hurrell and Davidsson are with the Swiss Federal Institute of Technology, Zürich, Switzerland. Dr. Bothwell is with the University of Witwatersrand, Johannesburg, South Africa. Dr. Cook is with the Kansas University Medical Center, Kansas City, Kansas, USA. Dr. Dary is with MOST, the Micronutrient USAID Program, Arlington, VA, USA. Dr. Fairweather-Tait is with the Institute of Food Research, Norwich, UK. Dr. Hallberg is with the University of Göteborg, Göteborg, Sweden. Dr. Lynch is with the Eastern Virginia Medical School, Norfolk, Virginia, USA. Dr. Rosado is with the Institute of Medical Sciences and Nutrition, Mexico City, Mexico. Dr. Walter is with the Institute of Nutrition and Food Technology, Santiago, Chile. Dr. Whittaker is with the US Food and Drug Administration, Washington DC, USA.

\section{Introduction}

Iron deficiency is a major public health problem in developing countries that affects up to $50 \%$ of infants, children, and women of childbearing age in poorer populations of Africa, Asia, and Latin America. Approximately one-half of these people suffers from the most severe form of iron deficiency, iron deficiency anemia (IDA). IDA is an important cause of cognitive deficits in infants and young children; ${ }^{1}$ it can cause premature birth $^{2}$ and increased maternal ${ }^{3}$ and perinatal mortality. ${ }^{4}$ IDA also has a profound effect on work performance and productivity. ${ }^{5,6}$ It has important negative economic consequences in countries where it is a major health problem. ${ }^{7}$ For health and economic reasons, therefore, many developing countries are evaluating strategies to combat iron deficiency. Whereas food fortification is usually considered the most cost-effective long-term approach to combat nutrient deficiencies, ${ }^{8}$ it should form part of a multiple-strategy approach that includes iron supplementation and dietary modification. Fortification of wheat flour with iron and vitamins has been used in the United States and some European countries for more than 50 years. Although wheat flour fortification was suggested as the main reason for the improved iron status of Swedish women, ${ }^{9}$ its efficacy has never been properly evaluated ${ }^{10}$ and its usefulness has been questioned. To understand the issues that underlie the current debate, it is helpful to consider the factors that influence the bioavailability of fortification iron.

\section{Factors Affecting the Bioavailability of Fortification Iron}

The amount of fortification iron absorbed from a particular diet depends on three factors. These include the composition of the diet, the iron status of individuals consuming the diet, and the relative bioavailability of the iron fortificant. ${ }^{11}$ There are two types of iron in the diet, heme iron (derived from hemoglobin and myoglobin) and nonheme iron (derived mainly from cereals, vegeta- 
bles, and fruit). Most forms of nonheme iron in a meal, whatever the origin, enter a common pool during digestion and are thus equally susceptible to a number of promoters and inhibitors of iron absorption. ${ }^{12}$ The major promoters of iron absorption are meat and ascorbic acid, ${ }^{12}$ whereas the major inhibitors are phytates and polyphenols. ${ }^{13}$

Soluble iron fortificants, such as ferrous sulfate, enter the common pool of nonheme iron completely and are absorbed to the same degree as is intrinsic nonheme iron in the diet. This iron is well absorbed when the diet contains adequate amounts of ascorbic acid and/or meat, but it is poorly absorbed from diets in which inhibitors of iron absorption predominate. ${ }^{14}$ Ferrous sulfate and other soluble iron complexes can only be used when the fortified cereal is consumed shortly after production; this is because they are chemically reactive and tend to produce undesirable organoleptic changes with time in the vehicles to which they are added. ${ }^{10,15,16}$

When cereal products will be stored for longer periods, fortificants that are less soluble in the upper gastrointestinal tract are frequently used. Although such inert compounds do not cause organoleptic changes when stored in a variety of vehicles, they tend to be less well absorbed because they are less soluble in gastric juice. Once dissolved, their absorption, like all iron present in the common pool, is dependent on the enhancers and inhibitors of iron absorption present in the meal and on the iron status of the consumer. The most widely used of these compounds, particularly in cereal products, is elemental iron. Elemental iron is relatively inexpensive and does not cause adverse flavor and color changes that often occur with prolonged storage of soluble iron compounds. Wheat and maize flours are selected as fortification vehicles because these foods are usually centrally processed and regularly consumed in sufficient quantities by at-risk population groups. There are, however, certain unanswered questions relating to the use of elemental iron because it is not a single entity but rather exists in various forms depending on the manufacturing process.

Three distinct families of elemental iron powders have been used: iron reduced by hydrogen or carbon monoxide, electrolytic iron, and carbonyl iron. Each manufacturing process produces a powder with a distinct particle size distribution, density, surface area, chemistry, and shape, all of which can affect iron bioavailability. The unique qualities of the various powders have largely been overlooked owing to the food industry's frequent use of the generic name "reduced iron." It is therefore not possible to give a single recommendation regarding the use of elemental iron powers in cereal fortification.

\section{Current Use of Iron Fortificants}

In 1941, the United States was the first country to enrich low-extraction wheat flour with iron and vitamins; by 1965 , virtually all white wheat flour and wheat bread and most corn meal (86-94\%), grits, and macaroni products were fortified with iron, as were a large proportion of other cereal products. ${ }^{17}$ By 1979 , most of the ready-to-eat breakfast cereals $(92 \%)$ were also fortified with iron (together with a selection of vitamins) to provide some $25 \%$ of the Recommended Daily Allowances per serving. ${ }^{18}$ And as commercial cerealbased weaning foods became popular, they were fortified with iron because infants are highly susceptible to iron deficiency. ${ }^{19,20}$

Mandatory enrichment of white wheat flour with iron was introduced in the United Kingdom and Canada in 1953 and many other countries have since introduced either mandatory or voluntary enrichment, usually adding sufficient iron to white wheat flour to restore the level to that in whole grain or $80 \%$-extraction flour (U.K.). Countries that require iron to be added to wheat flour include Chile (30 ppm), Guyana, Kenya, and Zambia (all 29-36 ppm), Nigeria (35 ppm), United Kingdom (16.5 ppm), United States (44 ppm), ${ }^{21}$ Mexico (24 ppm), and various Central American countries including El Salvador, Costa Rica, Guatemala, Honduras, Nicaragua, and Panama. In Germany, Holland, Belgium, Spain, and Switzerland, iron fortification of wheat flour is voluntary.

Because of its high nutritional bioavailability and low cost, fine dried ferrous sulfate is often the best iron source for fortification. It can be used in bakery flour (which is typically used within a month after milling), in semolina, and in other types of low-moisture wheat products such as noodles, macaroni, and spaghetti. More widespread use of ferrous sulfate is limited by the fact that it often causes rancidity in stored cereal flours and unwanted color changes in some cereal products. ${ }^{16,22}$ An alternative to ferrous sulfate is ferrous fumarate, which, although more expensive and insoluble in water, has a bioavailability similar to ferrous sulfate. It therefore causes fewer organoleptic problems and some European manufacturers use it to fortify infant cereals. $^{10}$

Elemental iron powders are, by far, the most widely used fortificants for wheat flour and other cereal products, including breakfast and infant cereals. ${ }^{23,24}$ Whereas elemental iron powders are the most widely used iron fortificants, many researchers have investigated whether they are sufficiently well absorbed from cereal products to be nutritionally useful. ${ }^{24-28}$ In several early human absorption studies, discrepant results were obtained, with bioavailability ranging from very low to figures equivalent to those obtained with ferrous sulfate. ${ }^{19,25-31}$ These 
differences can be ascribed to the fact that the labeled experimental powders were not produced in the same ways as commercial iron powders and, therefore, had different physico-chemical characteristics. Attempts to characterize the different iron fortification compounds according to their physicochemical characteristics, solubility in dilute acid, and ability to replete hemoglobin in iron-deficient rats ${ }^{32,33}$ revealed many differences. Interpretation of the various findings is complicated by failure to fully characterize the iron powders that were being tested. It was still possible to reach certain general conclusions: powders with smaller particle size, larger surface area, and greater solubility in dilute acid tended to be better absorbed.

From these findings it is clear that there is no generally accepted view whether or not elemental iron should be recommended for food fortification. To answer this question, SUSTAIN organized a workshop in Monterrey, Mexico, in September 2000, that brought together specialists in iron nutrition and iron fortification and representatives from companies that manufacture and distribute elemental iron powders. Published evidence was reviewed and a consensus, which summarized the current knowledge and made recommendations for the future, was prepared. The current report contains the literature review, together with the conclusions and recommendations from the SUSTAIN workshop. The following sections describe the characteristics of elemental iron powders used in food fortification and their bioavailability as measured by in vitro methods, by rat hemoglobin repletion studies, by human bioavailability studies, using radioactive or stable isotopes, and by monitoring iron status.

\section{Elemental Iron Powders Used in Food Fortification}

Historically, three distinct families of elemental iron powders have been used in food fortification. ${ }^{34}$ These are hydrogen-reduced and carbon monoxide-reduced "sponge" iron, electrolytic iron, and carbonyl iron. More recently, reduced iron powder manufactured by Quebec Metal Powders (QMP) has been added to the list of iron powders available for food fortification. The QMP reduced iron powder has been referred to as "atomized" iron. ${ }^{35}$ Owing to their different manufacturing methods, there are major differences in the chemical and physical properties of these families and their absorbability from foods. There are also considerable differences within individual powder types owing to the different grinding and sieving procedures used because of different particle size distributions. All commercial elemental iron powders for food fortification contain $>96 \%$ iron. The powder characteristics that influence absorption are those that influence its dissolution in the gastric juice. These include the microstructure of the particle (which depends on the method of manufacture), other metal impurities, particle size, shape, and surface area.

Hydrogen- and CO-reduced sponge iron powders are made at an elevated temperature by using hydrogen or carbon monoxide to reduce iron oxide to its elemental state. ${ }^{34}$ Two types of iron oxide are used to produce these reduced iron powders commonly referred to as "sponge" iron powders. The first is mill scale, a by-product of the steel industry; the second is natural iron ore. Mill scale mainly consists of $\mathrm{Fe}_{3} \mathrm{O}_{4}$ (magnetite) and is usually reduced by hydrogen, whereas iron ore consists of $\mathrm{Fe}_{2} \mathrm{O}_{3}$ (hematite) and is usually reduced by carbon monoxide. These compounds have the lowest purity of the foodgrade iron powders $(>96 \% \mathrm{Fe})$ and may contain elements such as $\mathrm{C}, \mathrm{Mg}, \mathrm{Al}, \mathrm{Si}, \mathrm{P}, \mathrm{S}, \mathrm{Cr}, \mathrm{Mn}, \mathrm{Ni}$, and $\mathrm{Cu}$, many of which are present as acid insoluble oxides and therefore would be expected to reduce solubility. The iron powders are ground by a variety of different milling techniques. Milling is usually carried out under an inert atmosphere to limit surface oxidation, the greatest source of impurity of any iron powder. The particle shape is considered sponge-like, irregular, and porous. QMP reduced iron powders are made by a different process. Details of the QMP process and other methods used to produce iron powders used in food enrichment can be found in the Handbook of Powder Metal Technologies and Applications. ${ }^{36}$

Electrolytic iron is produced in brittle sheets of elemental iron that are then ground into powders. The thin sheets are made by electrolytic migration of iron from a pure iron anode through a ferrous sulfate solution onto a stainless steel cathode. Electrolytic iron powders contain significantly fewer impurities than reduced iron powders $(>99 \% \mathrm{Fe})$, a quality that makes them ductile. The particle shape is described as highly irregular and fern-like with a high surface area. This material can easily be ground to a fine particle size, which, together with a large surface area and high purity, is an important factor in improving the solubility of elemental iron powders in gastric juice.

Carbonyl iron powders are manufactured directly from reduced elemental iron or from scrap iron. The metal reacts with carbon monoxide under heat and pressure to produce iron pentacarbonyl, which is then decomposed under controlled conditions yielding carbonyl iron powder and carbon monoxide gas. A second reduction treatment with hydrogen is necessary to remove the carbon impurities to produce powders containing $>98 \%$ iron, the major impurities being carbon and nitrogen. The carbonyl iron particles are dense spheres of extremely small particle size $(2-10 \mu \mathrm{m})$ whose structure is characterized by concentric shells of iron arranged in an onionlike fashion. The particles have a smooth, dense outer layer, which exposes them to less surface oxidation than 


\begin{tabular}{lll}
\hline \multicolumn{1}{c}{ Powder Type } & \multicolumn{1}{c}{ Manufacturer } & Particle Size* \\
\hline H-reduced (sponge) & North American Höganäs, USA & 325 mesh \\
Reduced & QMP, Canada & 325 mesh \\
CO-reduced (sponge) & Höganäs AB, Sweden & 325 mesh \\
& & 300 mesh \\
& & 100 mesh \\
Electrolytic & OMG Americas, USA (Glidden A131) & 325 mesh \\
& & $(39 \%<10 \mu \mathrm{m}, 35 \% 10-20 \mu \mathrm{m}, 16 \% 20-30 \mu \mathrm{m}$, \\
& & $8 \% 30-44 \mu \mathrm{m})$ \\
Electrolytic & IMP, India & 325 mesh \\
Carbonyl & BASF, Germany & 325 mesh $(>99.5 \%$ Fe or $>90 \% \mathrm{Fe})$ \\
Carbonyl & & $(10 \%<3.5 \mu \mathrm{m}, 50 \%<8.5 \mu \mathrm{m}, 100 \%<21 \mu \mathrm{m})$ \\
\hline
\end{tabular}

*325 mesh means that ca. $95 \%$ of particles are $<45 \mu \mathrm{m} ; 300$ mesh means that ca. $95 \%$ of particles are $<50 \mu \mathrm{m} ; 100$ mesh means that ca. $95 \%$ of the particles are $<150 \mu \mathrm{m}$.

reduced iron powders or electrolytic iron powders. A mixture of ferrous oxides and ferric oxides form on the surface of iron powders. Some oxidation is considered nutritionally beneficial because ferrous oxide is very soluble in gastric acid and the oxidized areas provide attack sites for particle dissolution. ${ }^{34}$

The milling and sieving procedures used determine the particle size of reduced and electrolytic iron powders. A powder generally consists of discrete particles of dry material with a maximum dimension of $1 \mathrm{~mm}$. Food Chemicals Codex (FCC) specifications ${ }^{37}$ require that reduced iron powders used to fortify foods are passed through a 100 -mesh sieve (particle size $<149 \mu \mathrm{m}$ ) and that electrolytic and carbonyl iron powders are passed through a 325-mesh sieve (particle size $<44 \mu \mathrm{m}$ ). Manufacturers also provide reduced iron powders that have been passed through a 325-mesh sieve. They form a large proportion of powders sold although this standard is not stipulated in the FCC. Whereas it would seem that particle size alone is insufficient to ensure enough iron is absorbed to be nutritionally useful, other factors such as surface area, porosity, or purity have not been sufficiently investigated to enable the formulation of clear guidelines. Only a few companies manufacture the vast majority of elemental iron powders used in food fortification today. Each company manufactures one type of powder using one manufacturing process. Reduced iron powders are manufactured by Höganäs $A B$, Sweden (CO-reduced); North American Höganäs (formerly Pyron Corporation), United States (H-reduced); and Quebec Metal Powders (QMP), Canada (reduced). Electrolytic iron powder is manufactured by OMG Americas, which is in the United States (formerly Glidden, A131), and International Metal Powders (IMP) India. BASF, Germany, and International Speciality Products (ISP), United States, manufacture carbonyl iron. The two newest companies to enter the market for food-grade iron powders are QMP and IMP. QMP started approximately 20 years ago and IMP began producing electrolytic iron in the early 1970s. Manufacturing companies sell the iron powders to the food ingredient suppliers and premix manufacturers who in turn supply the food industry. The characteristics of the different iron powders available on the market today are given in Table 1.

Hydrogen-reduced iron and electrolytic iron are provided as well-characterized single powders that should differ only slightly from batch to batch. Carbon monoxide-reduced iron powders can have variable composition depending on the market requirement. Three major particle sizes of CO-reduced iron are commercially available, including the large particle size 100-mesh, 300mesh for Europe, and 325-mesh for the United States. Carbonyl iron (BASF) is offered as $>99.5 \%$ iron or $>98 \%$ iron, but both products have the same particle size distribution with all particles being $<21 \mu \mathrm{m}$. Food companies in the United States and Europe mainly use the small particle size powders (i.e., $<50 \mu \mathrm{m}$ or $<45 \mu \mathrm{m}$ ). The large particle size CO-reduced iron $(<150 \mu \mathrm{m})$ is the least expensive product and is commonly used in many developing countries. These reduced iron powders are mainly used to fortify cereal flours and breakfast cereals. Electrolytic iron is mainly used to fortify infant cereals, particularly in the United States; however, it is also sometimes recommended for cereal flour fortification and is the specified iron compound in the micronutrient formula for wheat flour fortification in six countries in Central Asia. Carbonyl iron is only occasionally used to fortify foods because of its greater cost.

\section{Bioavailability of Elemental Iron Powders}

\section{In Vitro Methods}

Different in vitro methods have been used to estimate the bioavailability of elemental iron powders; there have 


\begin{tabular}{|c|c|c|c|}
\hline \multirow{2}{*}{$\begin{array}{l}\text { Authors } \\
\text { Ranhotra et } \text { ll. }^{43}\end{array}$} & \multicolumn{2}{|c|}{ Description of Powders } & \multirow{2}{*}{$\frac{\text { RBV }}{39}$} \\
\hline & Commercial & & \\
\hline \multirow[t]{2}{*}{ Pla et al. ${ }^{44}$} & Commercial 1 & 325 mesh & 50 \\
\hline & Commercial 2 & 325 mesh & 45 \\
\hline Pennell et al. ${ }^{45}$ & Glidden A131 & 325 mesh & 47 \\
\hline Coccodrilli et al. ${ }^{46}$ & Commercial & $98 \%<40 \mu \mathrm{m}$ & 70 \\
\hline \multirow[t]{3}{*}{ Shah et al. ${ }^{33}$} & Commercial 1 & $99 \%<40 \mu \mathrm{m}$ & 32 \\
\hline & Commercial 2 & $99 \%<40 \mu \mathrm{m}$ & 37 \\
\hline & Commercial 3 & $99 \%<40 \mu \mathrm{m}$ & 16 \\
\hline Sacks \& Houchin ${ }^{47}$ & Glidden A131 & & 48 \\
\hline Motzok et al. ${ }^{39}$ & Glidden & $99 \%<40 \mu \mathrm{m}$ & 42 \\
\hline Shah \& Belonje $\mathrm{e}^{48}$ & Commercial sa & le for cereals & $41-44$ \\
\hline Romanik \& Miller ${ }^{49}$ & Glidden A131 & & 59 \\
\hline Hurrell et al. ${ }^{22}$ & Glidden A131 & & 44 \\
\hline
\end{tabular}

been few studies, however, comparing in vitro results directly with rat hemoglobin repletion data or human absorption data. Results from in vitro studies therefore do not provide information that can be used to predict bioavailability of the different powders. In the future, however, these methods may provide a simple approach that could be used to optimize and characterize iron powders for food fortification.

Several authors have evaluated solubility in dilute $\mathrm{HCl}$, although the early studies of Pla and $\mathrm{Fritz}^{38}$ found poor agreement between the solubility of a range of iron compounds in dilute $\mathrm{HCl}(\mathrm{pH} 1.1)$ and their relative bioavailability in rat hemoglobin repletion studies. Shah et al. ${ }^{33}$ proposed that the suitability of elemental iron powders for food fortification should be judged by their solubility in dilute $\mathrm{HCl}$. To measure solubility, investigators recommended that $100 \mathrm{mg}$ powder be shaken with $250 \mathrm{~mL}$ of $0.2 \% \mathrm{HCl}(\mathrm{pH} 1.2)$ at $37^{\circ} \mathrm{C}$, and that only powders that are $>90 \%$ soluble after 3 hours should be used for food fortification. Motzok et al., ${ }^{39}$ using a similar method, showed that the solubility of elemental iron powders after 10 minutes in dilute acid agreed with relative bioavailability values (RBV) from rat studies. They reported $44 \%$ solubility of electrolytic iron, $45 \%$ and $31 \%$ with two different batches of carbonyl iron, $8 \%$ for CO-reduced iron, and $8 \%$ each for two different batches of H-reduced iron. Using the method of Shah et al., ${ }^{33}$ Forbes et al. ${ }^{40}$ reported that electrolytic iron was $75 \%$ dissolved in dilute $\mathrm{HCl}$ after 30 minutes and that the relative human absorption of electrolytic iron compared with ferrous sulfate was also $75 \%$. The other compound tested in this study was ferric orthophosphate, which was only 3 to $4 \%$ soluble in dilute acid after 30 minutes but was $25 \%$ as well absorbed as ferrous sulfate in man. Earlier, Björn-Rasmussen et al. ${ }^{31}$ reported a positive correlation between the solubility of four experimental reduced iron compounds in dilute $\mathrm{HCl}$ and their absorption in human subjects.
Forbes et al. ${ }^{40}$ also reported good agreement of iron absorption in man from electrolytic iron and ferric orthophosphate with in vitro dialyzable iron from those compounds as measured after a simulated gastric and intestinal enzymatic digestion. The same technique was also recommended by Whittaker et al. $^{41}$ as a useful method to predict the bioavailability of fortification iron in man, but a careful evaluation of different elemental iron powders using this method still remains to be made.

\section{Rat Studies}

In 1989, Forbes et al. ${ }^{40}$ reported that the Association of Official Analytical Chemists (AOAC) hemoglobin repletion test in rats ${ }^{42}$ was a good predictor of the RBV of an iron fortification compound in humans. In this assay, weaning rats are first rendered iron deficient and anemic by feeding a low-iron diet for 4 weeks; the rats are then repleted over 2 weeks with the test iron compounds. $\mathrm{RBV}$ of the iron compound is obtained by comparing the increase in hemoglobin of the test iron compound with the increase in hemoglobin with ferrous sulfate. Many hemoglobin repletion assays using the AOAC method were made on commercial iron powders used in the 1970 s and 1980s for cereal fortification mainly in the United States. Results from the assays are now presented and reviewed.

Electrolytic iron. Studies with electrolytic iron (Table 2) have reported RBV values from 16 to 70, with a mean of 44 , in commercial powders conforming to the FCC specifications ${ }^{37}$ that were passed through a 325mesh sieve. The commercial powder Glidden A131 was tested independently five times between 1975 and 1989, yielding RBV values from 42 to 59, with a mean of 48 . This electrolytic iron powder is still widely used to fortify infant cereals. ${ }^{50}$ Most, but not all, of the electrolytic iron powders had an RBV value of $>40$.

H-reduced iron. H-reduced iron powders (Table 3) reportedly have lower RBV values than electrolytic iron 
Table 3. Studies Using Relative Bioavailability (RBV) in Rats to Evaluate H-Reduced Iron

\begin{tabular}{|c|c|c|c|}
\hline Authors & \multicolumn{2}{|c|}{ Description of Powders } & RBV \\
\hline Ranhotra et al. ${ }^{43}$ & Commercial & & 37 \\
\hline Ranhotra et al. ${ }^{51}$ & Commercial & 325 mesh & $42-48$ \\
\hline \multirow[t]{2}{*}{ Pla et al. ${ }^{44}$} & Commercial & 325 mesh & 32 \\
\hline & Commercial & 100 mesh & 18 \\
\hline Fritz et al. ${ }^{32}$ & Commercial & & 27 \\
\hline Coccodrilli et al. ${ }^{46}$ & Commercial & $97 \%<40 \mu \mathrm{m}$ & 25 \\
\hline \multirow[t]{2}{*}{ Shah et al. ${ }^{33}$} & Commercial & $92 \%<40 \mu \mathrm{m}$ & 18 \\
\hline & Commercial & $88 \%<40 \mu \mathrm{m}$ & 24 \\
\hline \multirow[t]{2}{*}{ Motzok et al. ${ }^{39}$} & Glidden & $92 \%<40 \mu \mathrm{m}$ & 14 \\
\hline & Pyron & $99 \%<40 \mu \mathrm{m}$ & 13 \\
\hline \multirow[t]{5}{*}{ Sacks \& Houchin ${ }^{47}$} & \multicolumn{3}{|c|}{$\begin{array}{l}\text { Mallinkrodt no } 4350 \text { (mean particle } \\
\quad \text { size } 7 \mu \mathrm{m} \text { ) }\end{array}$} \\
\hline & \multirow[t]{2}{*}{ Mallinkrodt no 4353} & $5 \%<10 \mu \mathrm{m}$ & 27 \\
\hline & & $25 \%<20 \mu \mathrm{m}$ & 32 \\
\hline & Glidden B 131 & $3 \%<10 \mu \mathrm{m}$ & 35 \\
\hline & Mallinkrodt-100 mesh & $22 \%<20 \mu \mathrm{m}$ & 24 \\
\hline Ranhotra et al. ${ }^{52}$ & Commercial & & 49 \\
\hline Shah \& Belonje $\mathrm{e}^{48}$ & Mallinkrodt-325 mesh & $96 \%<44 \mu \mathrm{m}$ & 28 \\
\hline Hurrell et al. ${ }^{22}$ & \multicolumn{2}{|c|}{ Commercial—Riedel, Germany } & 54 \\
\hline
\end{tabular}

powders. Coarse powders that conform to FCC specifications ${ }^{37}$ by passing through a 100 -mesh sieve $(149 \mu \mathrm{m})$ have yielded RBV values of approximately $20 .^{32,47}$ The reported RBV values for other commercial powders have varied from 13 to 54 , with a mean of 30 . Commercial powders, most of which pass through a 325-mesh sieve, have also occasionally given low RBV values, i.e., $13^{39}$ and $25{ }^{46}$ The most recent commercial powder, tested in 1989, however, gave an RBV of $54 .^{22}$

CO-reduced iron. Only three studies have reported data on commercial CO-reduced iron powders (Table 4), yielding RBV values from 12 to 32 (mean 19); this indicates these powders have generally low bioavailability.

Carbonyl iron. All carbonyl iron powders pass through a 325-mesh sieve. Reported RBV values are between 27 and 66 (mean 47), and clearly depend on the mean particle size (Table 4). Powders in which $>90 \%$ of the particles are $<5 \mu \mathrm{m}$ have yielded a mean RBV value of 56, whereas the largest particle size commercial powder, in which $>80 \%$ of the particles were $<20 \mu \mathrm{m}$, had an RBV of 39.

Particle size versus method of manufacture. Whereas it is clear that particle size reduction increases the RBV of all iron powders, elemental iron powders of identical particle size manufactured by different methods have yielded different RBV values. Thus the RBV values for electrolytic iron powders of a specified particle size are higher than those for H-reduced iron of the same particle size, which is, in turn, higher than those for CO-reduced iron. ${ }^{54}$ (Table 5) Whereas direct comparisons between carbonyl iron powder and electrolytic pow-

Table 4. Studies Using Relative Bioavailability (RBV) in Rats to Evaluate Carbonyl and CO-Reduced Iron

\begin{tabular}{|c|c|c|c|}
\hline & Authors & Description of Powders & RBV \\
\hline \multirow[t]{10}{*}{ Carbonyl iron } & Pla et al. ${ }^{44}$ & $95 \%<5 \mu \mathrm{m}$ & 47 \\
\hline & Shah et al. ${ }^{33}$ & mean particle size $<4 \mu \mathrm{m}$ & 61 \\
\hline & & mean particle size $<3 \mu \mathrm{m}$ & 51 \\
\hline & Motzok et al. ${ }^{39}$ & $86 \%<10 \mu \mathrm{m}$ & 31 \\
\hline & & $93 \%<10 \mu \mathrm{m}$ & 27 \\
\hline & Sacks \& Houchin ${ }^{47}$ & $90 \%<5 \mu \mathrm{m}$ & 66 \\
\hline & & $90 \%<8 \mu \mathrm{m}$ & 63 \\
\hline & & $80 \%<20 \mu \mathrm{m}$ & 39 \\
\hline & Hurrell et al. ${ }^{22}$ & BASF & 52 \\
\hline & Kosonen \& Mutanen ${ }^{53}$ & Lohmann & 35 \\
\hline \multirow[t]{3}{*}{ CO-reduced iron } & Coccodrilli et al. ${ }^{46}$ & $88 \%<40 \mu \mathrm{m}$ & 32 \\
\hline & Shah et al. ${ }^{33}$ & $84 \%<40 \mu \mathrm{m}$ & 12 \\
\hline & Motzok et al. ${ }^{39}$ & Mallinkrodt $60 \%<40 \mu \mathrm{m}$ & 12 \\
\hline
\end{tabular}


Table 5. Influence of Particle Size on Bioavailability of Elemental Iron Powders

\begin{tabular}{lcc}
\hline Production Method & Particle Size $(\boldsymbol{\mu m})$ & RBV \\
\hline Electrolytic 1 & $7-10$ & 64 \\
& $27-40$ & 38 \\
Electrolytic 2 & $0-10$ & 76 \\
& $10-20$ & 75 \\
& $20-40$ & 48 \\
H reduction & $>40$ & 45 \\
& $10-20$ & 54 \\
CO reduction & $>40$ & 34 \\
& $6-10$ & 36 \\
Carbonyl & $14-19$ & 21 \\
& $27-40$ & 13 \\
& $<4$ & 69 \\
\hline
\end{tabular}

Adapted from Fritz. ${ }^{54}$

ders of identical particle size have not been made, carbonyl iron powders have yielded similar RBV values to electrolytic iron of the smallest particle size $(0-10 \mu \mathrm{m}$ or 7-10 $\mu \mathrm{m}$ ) in rat hemoglobin repletion studies. (Table 5)

Effect of processing. Animal studies indicate that neither bread baking nor infant cereal processing (wet mixing and drying) influence RBV. Pennell et al. ${ }^{45}$ reported that the RBV of an electrolytic iron powder was 47 when added directly to the rat diet, 49 when added to the rat diet with the unfortified rice infant cereal, and 45 when added to the diet after being processed with the rice cereal. Similarly, Shah \& Belonge ${ }^{48}$ reported that the RBV of a reduced iron powder was 26,28 , and 30 , respectively, when added to the rat diet directly, when added as part of iron fortified flour, and when baked into bread.

Extrapolation from rats to humans. The rat studies using the AOAC hemoglobin repletion test would therefore predict that the relative bioavailability to humans of the different commercial elemental iron powders, at least those marketed in the 1970s and 1980s, is variable and depends both on particle size and method of production. Electrolytic and carbonyl iron powders that pass through a 325-mesh sieve had the highest reported RBV values in rats and would be predicted to be approximately half as well absorbed in humans as ferrous sulfate. The rat studies indicate that reduced iron powders are less well absorbed than carbonyl or electrolytic iron powders and have a more variable absorption. The coarse H-reduced powders, which pass only through a 100-mesh sieve, like the commercial CO-reduced powders, are predicted to be approximately $20 \%$ as well absorbed as ferrous sulfate. The finer H-reduced powders, which pass through a 325 -mesh sieve, are predicted to be 20 to $50 \%$ as well absorbed as ferrous sulfate.

It is unclear how the elemental iron powders mar- keted today (Table 1) compare with those studied in rats 20 to 30 years ago. The manufacturing process for electrolytic iron would appear to have remained essentially unchanged although there is no documented evidence that the current electrolytic iron powders are identical to Glidden A-131. The manufacture of H-reduced and CO-reduced sponge iron powders and carbonyl powders may have changed to some extent although the basic processes are still the same. There are no clearly recognizable rat studies testing the bioavailability of the newer iron powders, such as the QMP reduced iron or the IMP electrolytic iron, which have been introduced within the last 30 years.

\section{Human Bioavailability Studies}

Seven human studies have been carried out to measure the bioavailability of elemental iron powders added to bread or infant cereal. (Table 6) In most studies, bioavailability of the iron powder was compared directly with that of ferrous sulfate added to the cereal product in an identical manner. Two studies compared the absorption of the iron powder with that of the common pool iron using an extrinsic radio-iron tag. The latter value should approximate the absorption of ferrous sulfate provided that the iron concentration of the pool iron is similar to that of the fortification iron. Six studies were made with experimental iron powders labeled with radioiron or stable iron isotopes. Although these experimental powders were sometimes very different from commercial powders, in most cases they were sufficiently well characterized so as to provide useful information. The remaining study by Hallberg et al. ${ }^{28}$ is the only study that has measured the absorption of a commercial iron powder (carbonyl iron) irradiated to produce labeled material. The amount of iron added per meal varied in the seven studies from 1 to $5 \mathrm{mg}$. In general, as the amount of iron added per meal increased, fractional absorption decreased, but the absolute amount of iron absorbed increased. ${ }^{55}$ Studies done prior to 1969 have not been considered because of difficulties in defining the characteristics of the iron powders tested.

\section{Hydrogen-reduced Iron}

Iron absorption by human subjects from H-reduced iron powders added to bread or infant cereal has been measured four times. (Table 6) A further study was done with reduced iron $^{55}$ but the method of production was not stated. The isotopically labeled iron powders tested were sometimes very different from the iron powders marketed today. In the one infant cereal study, ${ }^{19}$ absorption by infants from a small particle size powder $(5-10 \mu \mathrm{m})$ was $4 \%$ and equivalent to the absorption of ferrous sulfate. The relatively low absorption can be explained by the high iron dose $(5 \mathrm{mg} / 10 \mathrm{~g}$ cereal meal) and by the 
Percent

Absorption

from Ferrous

Sulfate or

\begin{tabular}{|c|c|c|c|c|c|c|}
\hline Author & Method & Compound & Meal & Subjects & $\begin{array}{l}\text { Absorption from } \\
\text { Elemental Iron }\end{array}$ & $\begin{array}{l}\text { Common } \\
\text { Pool* }\end{array}$ \\
\hline \multirow[t]{2}{*}{$\begin{array}{l}\text { Höglund \& } \\
\text { Reizenstein }\end{array}$} & $\begin{array}{l}\text { Radioactive } \\
\text { WBC }\end{array}$ & $\begin{array}{l}\text { Reduced iron. } \\
\text { Coarse: } \\
23 \% 20-30 \\
\mu \mathrm{m}, 48 \% \\
>30 \mu \mathrm{m}\end{array}$ & $\begin{array}{l}60 \mathrm{~g} \text { wheat } \\
\text { roll with } \\
1 \mathrm{mg} \mathrm{Fe}\end{array}$ & $\begin{array}{l}\text { Adults } 8-13 / \\
\text { group, } \\
\text { separate } \\
\text { groups }\end{array}$ & Course: $3.0 \pm 0.8$ & $19.8 \pm 5.7$ \\
\hline & & $\begin{array}{l}\text { Fine: } 97 \% \text { ca. } \\
5 \mu \mathrm{m}\end{array}$ & & & Fine: $9.0 \pm 5.7$ & \\
\hline Cook et al. ${ }^{27}$ & $\begin{array}{l}\text { Radioactive } \\
\text { WBC }\end{array}$ & $\begin{array}{l}\text { H-reduced } \\
\quad \text { iron, } \\
\text { 5-10 } \mu \mathrm{m}\end{array}$ & $\begin{array}{l}60 \mathrm{~g} \text { wheat } \\
\text { roll with } \\
3 \mathrm{mg} \mathrm{Fe}\end{array}$ & $\begin{array}{l}\text { Adults, } \\
\text { 8/group, } \\
\text { separate } \\
\text { groups }\end{array}$ & 8.6 & 9.1 \\
\hline Rios et al. ${ }^{19}$ & $\begin{array}{l}\text { Radioactive } \\
\text { WBC }\end{array}$ & $\begin{array}{l}\text { H-reduced } \\
\text { iron, } \\
5-10 \mu \mathrm{m}\end{array}$ & $\begin{array}{l}10 \mathrm{~g} \text { cereal } \\
\text { (wheat, oat, } \\
\text { malt) with } \\
5 \mathrm{mg} \mathrm{Fe} \\
\text { plus } \\
\text { formula }\end{array}$ & $\begin{array}{l}\text { Infants }(5-7 \\
\text { m) } 12 / 25 \\
\text { group, } \\
\text { separate } \\
\text { groups }\end{array}$ & $\begin{array}{l}4.0(\mathrm{SEM} \\
3.4-4.9)\end{array}$ & $\begin{array}{l}2.7 \text { (SEM } \\
2.3-3.2)\end{array}$ \\
\hline $\begin{array}{l}\text { Björn-Rasmussen } \\
\text { et al. }{ }^{31}\end{array}$ & $\begin{array}{l}\text { WBC plus } \\
\text { erythrocyte } \\
\text { incorporation }\end{array}$ & $\begin{array}{l}\text { H-reduced } \\
\text { iron }\end{array}$ & $\begin{array}{l}60 \mathrm{~g} \text { wheat } \\
\text { roll with } \\
1 \mathrm{mg} \mathrm{Fe}\end{array}$ & $\begin{array}{l}\text { Adults, 6-8/ } \\
\text { group, } \\
\text { paired }\end{array}$ & $\begin{array}{ll}\text { E11 } & 15.6 \pm 6.8 \\
\text { E12 } & 19.2 \pm 4.7 \\
\text { E12 } & 7.0 \pm 1.9 \\
\text { E14 } & 2.5 \pm 0.3\end{array}$ & $\begin{array}{l}18.5 \pm 7.7 \\
21.8 \pm 5.8 \\
10.6 \pm 2.8 \\
19.9 \pm 2.1\end{array}$ \\
\hline \multirow[t]{4}{*}{ Hallberg et al. ${ }^{28}$} & $\begin{array}{l}\text { Radioactive } \\
\text { WBC plus } \\
\text { erythrocyte } \\
\text { incorporation }\end{array}$ & $\begin{array}{l}\text { BASF, } \\
\text { carbonyl } \\
\text { iron }\end{array}$ & $\begin{array}{l}40 \mathrm{~g} \text { bread } \\
(1 \mathrm{mg} \mathrm{Fe}) \\
\text { with } \\
\text { margarine, } \\
\text { marmalade, } \\
\text { and coffee }\end{array}$ & $\begin{array}{l}\text { Adults, } 8-10 / \\
\text { group, } \\
\text { paired }\end{array}$ & 1.0 & 5.6 \\
\hline & & & $\begin{array}{l}40 \mathrm{~g} \text { bread } \\
(1 \mathrm{mg} \mathrm{Fe}) \\
\text { with } \\
\text { margarine, } \\
\text { and milk }\end{array}$ & & 0.5 & 5.5 \\
\hline & & & $\begin{array}{l}40 \mathrm{~g} \text { bread } \\
(1 \mathrm{mg} \mathrm{Fe}) \\
\text { with } \\
\text { hamburger, } \\
\text { potatoes, } \\
\text { and beans }\end{array}$ & & 1.7 & 12.7 \\
\hline & & & $\begin{array}{l}40 \mathrm{~g} \text { bread } \\
(1 \mathrm{mg} \mathrm{Fe}) \\
\text { with meat } \\
\text { soup }\end{array}$ & & 1.1 & 20.1 \\
\hline Forbes et al. ${ }^{40}$ & $\begin{array}{l}\text { Radioactive } \\
\text { erythrocyte } \\
\text { incorporation }\end{array}$ & $\begin{array}{l}\text { Electrolytic, } \\
10-30 \mu \mathrm{m}\end{array}$ & $\begin{array}{l}40 \mathrm{~g} \text { wheat } \\
\text { farina, } 120 \\
\mathrm{~mL} \text { milk, } \\
\text { and } 1 \mathrm{mg} \\
\mathrm{Fe}\end{array}$ & $\begin{array}{l}\text { Adults, 10/ } \\
\text { group, } \\
\text { paired }\end{array}$ & $\begin{array}{l}3.37 \text { (SEM } \\
2.62,4.35)\end{array}$ & $\begin{array}{l}4.52 \text { (SEM } \\
\quad 3.53,5.78)\end{array}$ \\
\hline $\begin{array}{l}\text { Roe \& } \\
\text { Fairweather- } \\
\text { Tait }^{56}\end{array}$ & $\begin{array}{l}\text { Stable } \\
\text { isotopes, } \\
\text { fecal } \\
\text { monitoring }\end{array}$ & H-reduced & $\begin{array}{l}\text { Bread roll } \\
\text { with } 1 \mathrm{mg} \\
\text { Fe and } \\
\text { Coca Cola }\end{array}$ & $\begin{array}{l}\text { Adults, 10/ } \\
\text { group }\end{array}$ & $64.8 \pm 4.2$ & - \\
\hline
\end{tabular}

*Absorption of ferrous sulfate added to cereal products in an identical manner to the elemental iron (References 19, 27, 40, 55) or absorption of pool iron as measured by extrinsic tag (References 28,31 ). WBC $=$ whole body counter. 
presence of phytic acid, even though the cereal was fed mixed with an infant formula, which can be assumed to contain ascorbic acid. The same small particle size iron powder $(5-10 \mu \mathrm{m})$ or ferrous sulfate, added to a lowextraction bread roll at a level of $3 \mathrm{mg}$ iron, gave an iron absorption of approximately $9 \%$ in adults. ${ }^{27}$ Compared with ferrous sulfate, the RBV of H-reduced iron was 95; this was much higher than the RBV values of 31 and 5 reported for ferric orthophosphate and sodium iron pyrophosphate, respectively.

In the three other studies with reduced iron, $1 \mathrm{mg}$ of iron was added and fed in a bread roll. Two of these studies were done with radioisotopes and used either a whole body counter or erythrocyte incorporation of the radioisotopes to evaluate iron absorption. In the study of Höglund and Reizenstein, ${ }^{55} 30 \mathrm{~g}$ white bread was fortified with $1 \mathrm{mg}$ radio-labeled reduced iron of the fine (ca. $5 \mu \mathrm{m})$ or coarse $(>48 \%$ of the particles $>30 \mu \mathrm{m})$ variety. Using a whole body counter, they compared elemental iron absorption in human volunteers with that of ferrous sulfate. Mean absorption of the "coarse" elemental iron was $3 \%$ and absorption of the "fine" elemental iron was $6 \%$, representing an RBV relative to ferrous sulfate of 15 and 45, respectively. Björn-Rasmussen et al. ${ }^{31}$ also fed $1 \mathrm{mg}$ of different radio-labeled experimental reduced iron powders in $60 \mathrm{~g}$ wheat rolls, made from $60 \%$-extraction wheat flour, to healthy volunteers and measured iron absorption by both hemoglobin incorporation and whole body counting. Absorption depended on the solubility of the powder in dilute acid, the surface area of the iron particles, and the particle size. In subjects with relatively low iron stores, iron absorption was 2.5 to $19 \%$, representing RBV values of 13 to $90 \%$ relative to absorption of native bread iron labeled extrinsically with ${ }^{59} \mathrm{FeCl}_{3}$.

The third, more recent study was done with stable isotopes. Iron absorption was measured from the amount of added iron isotope excreted in the stool in ten nonanemic adult females with moderately low iron stores (mean plasma ferritin $24 \mu \mathrm{g} / \mathrm{L}$ ). ${ }^{56}$ The reported absorption was $65 \%$, much higher than any previously reported values. The reduced iron powder used in this study was produced experimentally by a stable isotope manufacturer and was reported to have a solubility in dilute acid similar to that of a commercial reduced iron powder. There was no direct comparison with ferrous sulfate added to bread. There are two possible explanations for this unusually high absorption. Firstly, it is possible that the fecal monitoring technique used generated falsely high absorption values. This is suggested by the high mean iron absorption (50\%) from a reference dose of 3 $\mathrm{mg}$ iron as ferrous sulfate and $30 \mathrm{mg}$ ascorbic acid. A $40 \%$ reference dose absorption usually indicates that subjects have reduced iron stores. Secondly, the bread rolls were fed with Coca Cola , a beverage of low $\mathrm{pH}$, which could have facilitated the dissolution of the iron powder in the gastric juice and thus elevated absorption. Although the high absorption reported in this study is inconsistent with previous studies using radioisotopes and whole body counting, the results suggest that reduced iron powders of high relative bioavailability can be produced. This conclusion is in agreement with the results from earlier studies, ${ }^{19,27}$ which reported similar absorption values from $\mathrm{H}$-reduced iron powders and ferrous sulfate.

\section{Electrolytic Iron}

The electrolytic iron powder tested by Forbes et al. ${ }^{40}$ was similar but not identical to commercial electrolytic iron passing through a 325-mesh sieve (Glidden A-131). Absorption from a $3 \mathrm{mg}$ iron dose by adult volunteers of normal iron status from a meal of wheat farina and milk was $3.4 \%$, which represented $75 \%$ of the absorption of ferrous sulfate from the same meal. The addition of 100 $\mathrm{mg}$ ascorbic acid to the test meal increased the absorption of electrolytic iron to $8 \%$ without greatly changing its RBV value.

\section{Carbonyl Iron}

After extensive studies on the bioavailability in humans of carbonyl iron added to bread rolls, Hallberg et al. ${ }^{28}$ recommended the need to reconsider the rationale for using elemental iron powders for food fortification. These investigators irradiated food-grade carbonyl iron (BASF) in a nuclear reactor for approximately 10 days at a temperature of $\approx 100^{\circ} \mathrm{C}$. The powder was left to stand for at least 500 days so as to allow for the decay of ${ }^{59} \mathrm{Fe}$ and other unwanted radioisotopes, after which time the ${ }^{55} \mathrm{Fe}$-labeled carbonyl iron was added to $60 \%$-extraction wheat flour and baked into bread rolls. One, two, and three mg of carbonyl iron were added to each $40 \mathrm{~g}$ roll representing fortification levels of $2.5,5.0$, and $7.5 \mathrm{mg} /$ $100 \mathrm{~g}$ flour. A total of 15 separate iron absorption studies were carried out in seven to ten human subjects per study; fortified rolls were fed with marmalade, margarine, and coffee for breakfast or as part of a composite meal with either hamburger or vegetable/meat soup. Mean iron absorption from the breakfast meals was $1.4 \%$ (range 0.5-2.7\%), which represented a mean RBV value of 22 (range 9-33) when compared with the absorption of native meal iron labeled with ${ }^{59} \mathrm{FeCl}_{3}$. Mean $\mathrm{RBV}$ was even lower with the hamburger meals and meat/vegetable soup at 13 and 5 , respectively.

These results were somewhat surprising at the time because the reported RBV values in rats for carbonyl iron were closer to $50 .{ }^{47}$ The data on solubility and particle size, as well as the rat studies, had suggested carbonyl iron was at least as good as, if not better than, reduced iron and electrolytic iron. ${ }^{47}$ The carbonyl iron 
irradiated by Hallberg et al. ${ }^{28}$ was subsequently reported to have an RBV value in rats of $35 .{ }^{53}$ One might be tempted to suggest that the irradiation and storage of the commercial carbonyl iron powder may have changed its properties, but its solubility in dilute $\mathrm{HCl}$ at $\mathrm{pH} 1$ and $\mathrm{pH}$ 3 was unchanged and similar to that of a commercial electrolytic iron powder (Glidden A-131). After 30 minutes, $85 \%$ of all tested compounds dissolved at $\mathrm{pH} 1$ but only $6 \%$ dissolved at $\mathrm{pH} 3$. Hallberg et al. ${ }^{28}$ suggested that differences in gastric $\mathrm{pH}$ after a meal and different gastric residence time could be extremely important factors because the variation in RBV of carbonyl iron observed with the different meals was probably due to different rates and extent of solubility of the iron powder in the gastric juice. Owing in part to the results of this study, iron fortification of wheat flour with carbonyl iron was discontinued in Sweden some 10 years later.

\section{Predicting the Absorption of Elemental Iron Based on the Measured Absorption of Ferrous Sulfate}

Another way to predict the absorption of elemental iron powders from a cereal product is to relate it to the measured absorption of ferrous sulfate. At best, the absorption of an elemental iron powder would be equivalent to that of ferrous sulfate, but, in most cases, it would be much less. Rat assays would predict that electrolytic and carbonyl iron powders are approximately half as well absorbed as ferrous sulfate and that reduced iron powders are 20 to $50 \%$ as well absorbed as ferrous sulfate. (Tables 2-4) Studies reporting iron absorption by human subjects from ferrous sulfate-fortified bread and infant cereals are listed in Table 7. Iron absorption by adults with normal iron status from bread rolls made from $60 \%$-extraction flour containing 1.7 to $2.5 \mathrm{mg}$ iron as ferrous sulfate was reported to be 5.7 to $8.6 \%$. $^{60,61}$ Iron absorption by adults from wheat rolls made from $80 \%$-extraction flour, however, fell to approximately $1 \%$, presumably owing to the high phytic acid content. Iron absorption by infants from whole grain infant cereal, whole meal bread, and a breakfast cereal was similarly low (3.1-3.8\%). ${ }^{57,59}$ Phytic acid is a potent inhibitor of iron absorption ${ }^{62,63}$ but can be partially degraded during the yeast fermentation step of the bread baking process, and completely degraded if low-extraction flour and prolonged fermentation times are used. ${ }^{61,62}$ Another effective means of increasing the bioavailability of fortification iron is to add ascorbic acid-a potent enhancer of iron absorption-to cereal porridges and infant cereals. ${ }^{35}$ Its effectiveness has been shown in several studies. For example, iron absorption from a commercial infant cereal, based on wheat and cow's milk and fortified with ferrous sulfate and ascorbic acid, was reported to be $8.7 \%$ in infants ${ }^{58}$ and 2.6 to $4.3 \%$ in adults. ${ }^{22}$ Without the addition of ascorbic acid, iron absorption by adults from a ferrous sulfate-fortified wheat porridge was $2.2 \%$; this number fell to $<1 \%$ when soy protein isolate was added. ${ }^{61}$ Iron absorption by infants from whole meal bread fortified with ferrous sulfate increased from $3.1 \%$ to $7.5 \%$ when the bread was consumed with a drink containing $50 \mathrm{mg}$ ascorbic acid. ${ }^{57}$

\section{Extrapolation of Findings to Elemental Iron}

There are two concerns when attempting to predict the absorption of an elemental iron powder from a fortified cereal product. The first concern is that the elemental iron powder is less bioavailable than ferrous sulfate because it does not dissolve as well in the gastric juice. The second concern relates to the nature of the diet. The proportion of elemental powder that is available for absorption is then exposed to inhibitors, such as phytic acid, so that the amount finally absorbed may be reduced to unacceptably low levels. From the published human bioavailability studies, only Hallberg et al. $^{28}$ tested a commercial iron powder and reported absorption values of 1 to $2 \%$ in subjects with normal iron status consuming composite meals together with the fortified bread roll. Forbes et al. ${ }^{40}$ tested an experimental electrolytic iron powder of similar particle size to the commercial powder that was passed through a 325-mesh sieve and reported an absorption of $3.4 \%$ for a meal based on wheat farina and milk.

Much higher absorption values from experimental elemental iron powders and ferrous sulfate have been reported when the iron compound is fed with a simple bread meal and when low-extraction flour containing little or no phytic acid is used to make the bread. With 1 mg added iron, absorption values as high as 10 to $20 \%$ have been reported in subjects with normal iron status (Table 6) for both elemental iron powders and ferrous sulfate. With 1.7 to $2.5 \mathrm{mg}$ added iron, reported absorption is in the range of 6 to $9 \%$. (Table 7) In the presence of phytic acid, however, such as in bread made from $80 \%$-extraction or whole meal flour, iron absorption from ferrous sulfate may fall to $1 \%$ or less. (Table 7)

\section{Human Studies Monitoring Iron Status}

Elwood et al. ${ }^{64}$ tried, in two separate studies, to demonstrate the beneficial effect of the U.K. flour enrichment program $(16 \mathrm{mg}$ iron $/ \mathrm{kg}$ ) on the iron status of free-living women. The first study was a therapeutic trial monitoring the influence of iron-fortified bread as an integral part of the normal diet on the hemoglobin concentration of mildly anemic women. The second study was termed a prophylactic trial because the anemic women were first treated with iron to increase their hemoglobin concentration; then the ability of the iron-fortified bread to maintain the higher hemoglobin levels was monitored. In 
Table 7. Iron Absorption in Human Subjects from Ferrous Sulfate-fortified Bread and Infant Cereals

\begin{tabular}{|c|c|c|c|c|}
\hline Author & Method & Meal & Subjects & \% Iron Absorption \\
\hline Hurrell et al. ${ }^{22}$ & $\begin{array}{l}\text { Radioisotopes, } \\
\text { erythrocyte } \\
\text { incorporation }\end{array}$ & $\begin{array}{l}100 \mathrm{~g} \text { wheat } / \mathrm{milk} \\
\text { infant cereal } \\
300 \mathrm{~mL} \text { water, } 7.5 \mathrm{mg} \\
\mathrm{Fe}, 35 \mathrm{mg} \text { ascorbic } \\
\text { acid }\end{array}$ & $\begin{array}{l}\text { Adults, 10-13 subjects/ } \\
\text { study }\end{array}$ & $\begin{array}{l}2.58(\text { SEM } 1.82,3.66) \\
4.28(\text { SEM } 3.17,5.78)\end{array}$ \\
\hline \multirow[t]{2}{*}{ Faiweather-Tait et al. ${ }^{57}$} & $\begin{array}{l}\text { Stable isotopes, } \\
\text { erythrocyte } \\
\text { incorporation }\end{array}$ & $\begin{array}{l}\text { Weetabix breakfast, } 20 \\
\text { g cereal, } 85 \mathrm{~g} \mathrm{milk} \text {, } \\
0.7 \mathrm{mg} \mathrm{Fe}, 4 \mathrm{mg} \\
\text { ascorbic acid }\end{array}$ & $\begin{array}{l}\text { Infants, } 9 \text { months, } 10 \\
\text { subjects/group }\end{array}$ & $3.0(\mathrm{SD} \mathrm{1.1,8.3)}$ \\
\hline & & $\begin{array}{l}22 \mathrm{~g} \text { whole wheat } \\
\text { bread, } 6 \mathrm{~g} \\
\text { margarine, } 0.5 \mathrm{~g} \\
\text { marmite, } 0.6 \mathrm{mg} \mathrm{Fe}, \\
0.3 \mathrm{mg} \text { ascorbic acid }\end{array}$ & & $3.1(\mathrm{SD} 1.4,6.7)$ \\
\hline Davidsson et al. ${ }^{58}$ & $\begin{array}{l}\text { Stable isotopes, } \\
\text { erythrocyte } \\
\text { incorporation }\end{array}$ & $\begin{array}{l}25 \mathrm{~g} \text { wheat/milk infant } \\
\text { cereal, } 100 \mathrm{~mL} \\
\text { water, } 2.5 \mathrm{mg} \mathrm{Fe}, \\
\text { ascorbic acid/Fe } 2: 1 \\
\text { molar ratio }\end{array}$ & $\begin{array}{l}\text { Infants, } 5-9 \text { months, } \\
12 \text { subjects/study }\end{array}$ & 8.7 (range $3.8-10.9$ ) \\
\hline Fox et al. ${ }^{59}$ & $\begin{array}{l}\text { Stable isotopes, } \\
\text { erythrocyte } \\
\text { incorporation }\end{array}$ & $\begin{array}{l}20 \mathrm{~g} \text { whole grain } \\
\text { weaning cereal } \\
\text { (wheat, rice, oat, } \\
\text { rye, wheat bran), } 1.6 \\
\text { mg Fe }\end{array}$ & $\begin{array}{l}\text { Infants, } 9 \text { months, } 24 \\
\text { subjects/study }\end{array}$ & $3.8($ SEM $2.9,4.7)$ \\
\hline Hurrell et al. ${ }^{60}$ & $\begin{array}{l}\text { Radioisotopes, } \\
\text { erythrocyte } \\
\text { incorporation }\end{array}$ & $\begin{array}{l}50 \mathrm{~g} 60 \% \text {-extraction } \\
\text { wheat bread roll, } 1.7 \\
\mathrm{mg} \mathrm{Fe}\end{array}$ & $\begin{array}{l}\text { Adults, } 7 \\
\quad \text { subjects/study }\end{array}$ & 8.64 (SEM 6.0, 12.4) \\
\hline \multirow[t]{4}{*}{ Hurrell et al. ${ }^{61}$} & $\begin{array}{l}\text { Radioisotopes, } \\
\text { erythrocyte } \\
\text { incorporation }\end{array}$ & $\begin{array}{l}50 \mathrm{~g} 60 \% \text {-extraction } \\
\text { wheat bread roll, } 2.5 \\
\mathrm{mg} \mathrm{Fe}\end{array}$ & $\begin{array}{l}\text { Adults, 8-10 subjects/ } \\
\text { study }\end{array}$ & 5.7 (SEM 4.30, 7.55) \\
\hline & & $\begin{array}{l}50 \mathrm{~g} 80 \% \text {-extraction } \\
\text { wheat bread roll, } 2.5 \\
\mathrm{mg} \mathrm{Fe}\end{array}$ & & $0.99($ SEM $0.72,1.36)$ \\
\hline & & $\begin{array}{l}50 \mathrm{~g} 60 \% \text {-extraction } \\
\text { wheat cereal } \\
\text { porridge, } 5 \mathrm{mg} \mathrm{Fe}\end{array}$ & & $2.2($ SEM 1.36, 2.91) \\
\hline & & $\begin{array}{c}50 \mathrm{~g} \text { wheat/soy cereal } \\
\text { porridge, } 5 \mathrm{mg} \mathrm{Fe}\end{array}$ & & 0.73 (SEM $0.49,1.07)$ \\
\hline
\end{tabular}

the first trial, bread was fortified with either reduced iron or ferric ammonium citrate and provided approximately $1 \mathrm{mg}$ extra iron per day, which increases the daily iron intake by approximately $10 \%$. In the second trial, bread was fortified with ferric ammonium citrate at a higher level $(27 \mathrm{mg} / \mathrm{kg}$ instead of $16 \mathrm{mg} / \mathrm{kg})$, which provided $2.7 \mathrm{mg}$ extra iron per day. Elwood et al. ${ }^{64}$ concluded that neither trial provided conclusive evidence of any beneficial effect of wheat flour fortification on iron status, even though the reduced iron-fortified bread gave a small but statistically significant increase in hemoglobin $(0.24 \mathrm{~g} / \mathrm{dL})$ after 9 months of intervention. In another study, Elwood ${ }^{30}$ carried out a therapeutic trial that fed reduced iron-fortified bread to a group of anemic pa- tients in a mental hospital. He found no beneficial effect on hemoglobin after periods of 3 to 6 months, although a similar amount of iron given as ferrous gluconate caused a rise in mean hemoglobin in another group of anemic patients.

There is only one published study reporting improved iron status in a population fed regularly with an elemental iron-fortified cereal. This study was done in Chile by feeding an infant cereal fortified with Glidden A131 electrolytic iron. ${ }^{50}$ Iron status was monitored in groups of approximately 100 infants from 4 months to 15 months of age. The infants consumed $25-30 \mathrm{~g}$ rice infant cereal per day, either unfortified, or fortified with $55 \mathrm{mg}$ electrolytic iron/100 g, which provided some 14 to $17 \mathrm{mg}$ 
additional iron per day. The cereals were mixed with a non-iron-fortified formula containing $66 \mathrm{mg}$ ascorbic acid/L. Some infants continued to be breastfed, whereas others were fed the non-iron-fortified formula, both in addition to their normal diet that included fruits and fruit juices from 3 months, meat, and vegetables from 4 months, and regular table foods from 9 months. At 15 months, $15 \%$ of the breastfed infants consuming the non-iron-fortified cereal were diagnosed with IDA, compared with only $3 \%$ of those infants consuming the cereal fortified with electrolytic iron. In the infants fed the non-iron-fortified formula, the corresponding numbers were 17 and $6 \%$. The authors concluded that cereal fortified with electrolytic iron could contribute substantially to preventing IDA. Whereas this is true, it should be emphasized that IDA was not eradicated completely in this study even though the cereal provided an extra 14 to $17 \mathrm{mg}$ iron per day. The iron was ingested with a formula containing ascorbic acid, which facilitates absorption, and was in addition to the iron provided in the normal diet. Assuming 5\% absorption from the fortification iron, enough iron would be absorbed from the cereal to provide most of the iron requirement of a 6- to 12-month-old infant, which is estimated to be $0.9 \mathrm{mg} /$ day. ${ }^{65}$

\section{Adapting Iron Fortification to Different Dietary Settings}

Ultimately, the usefulness of elemental iron for food fortification depends on the ability of the fortified food, when consumed as part of the normal diet, to prevent iron deficiency in at-risk population groups. Iron bioavailability, which is a key factor in this process, depends on the nature and level of elemental iron added to the food, the amount of fortified food consumed, the iron status of the consumer, and the presence of inhibitors and enhancers of iron absorption in the cereal vehicle and the overall diet.

A successful iron fortification strategy is much more easily established in industrialized countries than in developing countries. From a logistic standpoint, the preparation and distribution of fortified cereals are usually more efficient and the mixed diets consumed by such populations contain fewer inhibitors of iron absorption and more enhancers, such as meat and ascorbic acid. By contrast, central distribution is often a problem in developing countries. In addition, staple cereal diets have high phytate and low ascorbic contents, whereas other inhibitors, such as polyphenols, which are present in tea, legumes, and sorghum, often pose an added problem. ${ }^{13,14}$ As a result, the absorption of all fortification compounds would be expected to be low. ${ }^{61}$ In developing countries, the problem of iron fortification is also complicated by a number of other factors. In addition to poor bioavailability of iron from cereal-based diets, helminth infections and particularly blood loss from hookworm infections ${ }^{66}$ contribute to the problem of iron deficiency in many areas. Other important etiologic factors expected to blunt the effect of fortification programs include folate deficiency, ${ }^{67}$ vitamin A deficiency, ${ }^{68}$ a variety of infections including malaria and HIV infection, ${ }^{69}$ and hemoglobinopathies. ${ }^{70}$

As mentioned above, it is possible to enhance iron absorption from commercial infant cereals fortified with elemental iron powders and other iron compounds by the addition of ascorbic acid ${ }^{35,42}$ or by phytate degradation. ${ }^{35,58}$ It is much more difficult to do so in developing countries, however, because ascorbic acid is unstable when stored in hot and humid climates unless it is encapsulated or stored in sophisticated packaging. Whereas nutritional campaigns to encourage the consumption of more fruits and vegetables or muscle tissue in the diet are highly desirable, such approaches are not always possible or practical. Sodium EDTA, which is stable during storage, is another potential enhancer of fortification iron absorption. It has been demonstrated to enhance the absorption of ferrous sulfate from cereal foods, ${ }^{61}$ but its influence on the absorption of elemental iron powders remains to be established.

\section{Conclusions and Recommendations}

The following conclusions are based on the preceding literature review and discussions, which took place at and after the SUSTAIN workshop in Monterrey.

Fortification of milled, refined cereals is a convenient way to deliver iron and other micronutrients to a general population whose diets are deficient in those micronutrients. Iron should be included in cereal fortification or enrichment programs in countries in which IDA is prevalent.

Because of its high bioavailability and low cost, FCC-grade dried ferrous sulfate is often the best iron source when cereals are to be stored for only short periods. It can be used in bakery flour, semolina, and other types of low-extraction wheat flours, which are normally used within one to two months after production. Ferrous sulfate should be a fine-particle size, dried material. FCC-grade ferrous fumarate is another good choice because it has a bioavailability similar to that of ferrous sulfate. It is insoluble in water and therefore causes fewer organoleptic problems than the more soluble ferrous sulfate. However, it is typically more costly than ferrous sulfate.

Elemental iron powders have been used for cereal fortification for more than 50 years and continue to be the most widely used iron compound for this purpose. They have the advantage of causing few, if any, color and flavor problems in stored food vehicles. They are 
inexpensive and suitable for fortification of staple foods such as wheat flour and maize flour. Absorption of elemental iron powders is lower than that of other iron fortificants, such as ferrous sulfate and ferrous fumarate, and is less predictable.

From the information currently available, there are three major types of iron powders in use:

- Reduced iron (North American Höganäs [H-reduced], Höganäs AB [CO-reduced], Quebec Metal Powders [reduced])

- Electrolytic iron (OMG Americas; Industrial Metal Powders)

- Carbonyl iron (BASF, International Speciality Powders)

FCC guidelines specify that reduced iron powders must have a particle size of $<150 \mu \mathrm{m}$ (100 mesh). Electrolytic and carbonyl iron powders must have a particle size of $<45 \mu \mathrm{m}$ (325 mesh). Based on current information, the relative costs of available elemental iron powders vary by a factor of approximately seven, with carbonyl iron being the most expensive and 100-mesh reduced iron the least expensive. Most reduced iron powders currently used to fortify foods in North America and Europe have a particle size of 300 or 325 mesh. Reduced iron of larger particle size (100 mesh), however, is being used in some developing countries, presumably because of the lower cost.

Elemental iron powders have been evaluated in several ways in relation to potential absorption in man. The methods used include the measurements of physicochemical characteristics, solubility in dilute acid, dialysability in vitro, hemoglobin repletion in anemic rats, bioavailability in human isotopic studies, and human efficacy studies. Although useful information has been obtained from all of these studies, it is important to emphasize the lack of uniformity in solubility and dialysability experiments. By contrast, hemoglobin repletion studies in rats have provided seemingly valid data on the commercial elemental iron powders in use at the time of the studies. The powders tested between 1971 and 1991, however, may have had different characteristics from those currently available. With one or two exceptions, the elemental powders tested in human bioavailability studies were very different from commercially available products.

\section{Reduced Iron Powders}

Results from rat studies on commercial reduced iron powders done between 1971 and 1991 indicated that hydrogen-reduced powders were less well absorbed than electrolytic iron and that carbon monoxide-reduced powders were very poorly absorbed. Because it is not known whether the reduced iron powders tested are the same as those presently being produced, there is no available evidence to evaluate the usefulness of reduced iron powders currently used for food fortification. Until it can be demonstrated that large particle size reduced iron powders of $<150 \mu \mathrm{m}$ (100 mesh) have a bioavailability equivalent to $<45 \mu \mathrm{m}$ (325 mesh) powder, they cannot be recommended for food fortification.

Human bioavailability studies with isotopes have shown that small particle size powders $(<10 \mu \mathrm{m})$ are absorbed as well as ferrous sulfate. However, the technical feasibility and cost of producing such powders have not been evaluated. Whereas particle size has been a major criterion in assessing reduced iron powders, it is possible that novel production techniques may lead to soluble particles of larger size in the future.

\section{Electrolytic Iron}

The information currently available suggests that electrolytic iron $(<45 \mu \mathrm{m}, 325$ mesh, with a dendritic structure similar to Glidden A131) should be a useful iron fortificant. This is based on the following evidence: an improvement in iron status of infants consuming an electrolytic iron-fortified infant cereal; a human bioavailability study with radio-labeled electrolytic iron having similar but not identical characteristics to the commercial products resulting in an absorption $75 \%$ of that of ferrous sulfate; and rat hemoglobin repletion studies with electrolytic iron powders similar to those being marketed today showing a relative bioavailability approximately $50 \%$ of that of ferrous sulfate.

\section{Carbonyl Iron}

Carbonyl iron has limited value in food fortification because of its high cost. There is also conflicting evidence concerning its bioavailability. Rat hemoglobin repletion studies with carbonyl iron powders have shown relative bioavailability of approximately $50 \%$ of that of ferrous sulfate; whereas it has been used therapeutically in very large doses ( $>1.5 \mathrm{~g} /$ day $)$, however, the absorption has been found to be very low $(0.5-2.0 \%)$. Finally, extensive bioavailability studies with irradiated carbonyl iron in a variety of meals have demonstrated a low RBV of $5 \%$ to $33 \%$.

\section{Fortification Efficacy}

Iron fortification of cereals has been used widely as a public health intervention strategy. In industrialized countries with high bioavailability diets, this strategy has been assumed to have a beneficial effect on iron status. In populations consuming low bioavailability diets, such as those consumed in many developing countries, the potential benefit may be much less, and much greater amounts of fortification iron may have to be added. Because the impact of fortifying low bioavailability diets may be limited and because changes in iron status take place slowly, fortification should be considered as only one of several strategies. Other strategies could include 
improving the overall quality of the diet by including promoters of iron absorption (e.g., ascorbic acid in citrus fruits, ripe papaya, and guavas, etc.); adding a facilitator of iron absorption, such as EDTA or ascorbic acid, to the fortified food vehicle; reducing the content of inhibitors consumed with meals (e.g., tea, coffee, or cocoa products); and adding the fortification iron to a food vehicle consumed separately from the main inhibitory meals.

\section{The Way Ahead}

Not enough is known about the characteristics and relative bioavailability of the commercial elemental iron powders that are currently available. Because only a few powders are used, it is suggested that these powders can be screened using a variety of established methods. Initially, these tests should all be conducted on the same batch of iron powder to establish comparability between laboratories and should include physicochemical characteristics, solubility in dilute acid, in vitro dialysability, CaCo-2 cell uptake, and hemoglobin repletion test in rats. At the same time, human bioavailability can be evaluated by serum iron curves, isotopic measurements of absorption (the labeled powders used in such studies must be prepared with characteristics as close as possible to the commercial powders), and by measuring the effect on iron status of human populations in field efficacy trials.

The current specifications for elemental iron powders are based on particle size, but there is evidence that other factors may be as important, or more important, in predicting bioavailability. By correlating the results of bioavailability studies with in-vitro tests, it should be possible to develop standardized techniques for predicting bioavailability. The development of a standardized test, based on solubility within a specific $\mathrm{pH}$ range, appears to be an attractive option. Once we have better characterized the iron powders available today, and developed simple, reliable quality control methodologies, it should be possible to manufacture and select suitable elemental iron powders for food fortification.

\section{Acknowledgements}

The authors are grateful to SUSTAIN for commissioning this literature review and for organizing the Monterrey workshop, and in particular to Liz Turner and Erica Stewart for their excellent organization and administration of the project. Appreciation is also extended to representatives from the iron powder industry for their input into this review. In addition, the authors acknowledge the technical contribution of the following persons: Guillermo Arteaga, MASECA, Monterrey, Mexico; Maria Leticia Bravo Gutierrez, Monterrey Institute of Technology, Monterrey, Mexico; Margarita Diaz Martinez, National Institute of Medical Sciences and Nutri- tion, Mexico City, Mexico; Fredrik Eklund, Höganäs AB, Höganäs, Sweden; Steven Harrison, Trace Science International, Ontario, Canada; Erhard Klar, OMG Americas, North Carolina, USA; Alberto Morales Lira, MINSA, Edo, Mexico; Peter Ranum, SUSTAIN, Washington DC, USA; Steve Schorn, Research Products, Salina, Kansas, USA; and Wolfgang Vogl and Dr. Paul Lohmann, Emmerthal, Germany. Alfonso Tirado (SUSTAIN) collected information on current iron powders and Elizabeth Turner (SUSTAIN) helped in editing the manuscript. This review is a modified version of one that was commissioned by SUSTAIN (Sharing United States Technology to Aid in the Improvement of Nutrition) and prepared for a workshop to address conflicting data on absorption of elemental iron and evaluate its usefulness as a cereal fortificant. The workshop was convened in Monterrey, Mexico in September 2000.

1. Lozoff $B$, Jiménez $E$, Xolf AW. Long term development outcome of infants with iron deficiency. $N$ Engl J Med 1991;325:687-694.

2. Scholl TO, Hediger M, Fischer RL, Shearer JW. Anemia vs iron deficiency: increased risk of preterm delivery in a prospective study. Am J Clin Nutr 1992;55:985-988.

3. Rush D. Nutrition and maternal mortality in the developing world. Am J Clin Nutr 2000;72:212S-240S.

4. Murphy JF, O'Riardon J, Newcombe RG, Coles EC, Pearson JF. Relation of haemoglobin levels in first and second trimesters to outcome of pregnancy. Lancet 1986;i:992-994.

5. Basta SS, Soekirman MS, Karyadi D, Scrimshaw NS. Iron deficiency anemia and the productivity of adult males in Indonesia. Am J Clin Nutr 1979;32: 916-925.

6. Edgerton VR, Gardner GW, Ohiray Y, Gunawadena $K A$, Senewiratne B. Iron-deficiency anaemia and its effect on worker productivity pattern. BMJ 1979;2: 1546-1549.

7. Ross J, Horten S. Economic consequences of iron deficiency. Ottawa: The Micronutrient Initiative; 1998.

8. Levin HM, Pollitt E, Galloway R, Mc Guire J. Micronutrient deficiency disorders. In: Jamison DT, Mosley WH, Measham AR, Bobadilla JB, eds. Disease Combat Priorities in Developing Countries. New York: University Press; 1993:421-451.

9. Hallberg L, Bengtsson C, Garby L, Lennartsson J, Rossander $\mathrm{L}$, Tiblin $\mathrm{E}$. An analysis of factors leading to a reduction in iron deficiency in Swedish women. Bull World Health Organ 1989;57:947-954.

10. Hurrell RF. Iron. In: Hurrell RF, ed. The Mineral Fortification of Foods. 1st edition. Surrey: Leatherhead Publishing; 1999:54-93.

11. Bothwell TH, MacPhail AP. Prevention of iron deficiency by food fortification. In: Fomon SJ, Zlotkin S, eds. Nutritional Anaemias. Nestlé Nutrition Workshop series 30. New York: Raven Press; 1992:183192.

12. Hallberg L. Bioavailability of dietary iron in man. Annu Rev Nutr 1981;1:123-147.

13. Gillooly M, Bothwell TH, Torrance JD, et al. The 
effects of organic acids, phytates and polyphenols on iron absorption from vegetables. Br J Nutr 1983; 49:331-342.

14. Fairweather-Tait SJ, Hurrell RF. Bioavailability of minerals and trace elements. Nutr Res Rev. 1996;9: 295-324.

15. Cook JD, Reusser M. Iron fortification: an update. Am J Clin Nutr 1983;38:648-659.

16. Hurrell RF. Bioavailability of different iron compounds to fortify formulas and cereals: technological problems. In: Steckel A, ed. Iron nutrition in infancy and childhood. New York: Raven Press; 1984:147-178.

17. Bauernfiend C, DeRitter E. Foods considered for nutrient addition: cereal grain products. In: Bauernfiend JC, Lachance PA, eds. Nutrient Additions to Foods. Connecticut: Food and Nutrition Press; 1991:143-209.

18. Hayden EB. Breakfast cereals: trend foods for the 1980's. Cereal Food World 1980;25:141-143.

19. Rios E, Hunter RE, Cook JD, Smith NJ, Finch CA. The absorption of iron as supplements in infant cereal and infant formula. Pediatrics 1975;55:686693.

20. Lynch SR, Hurrell RF. Iron in formulas and baby foods. In: Lönnerdal B, ed. Iron Metabolism in Infants. Boca Raton: CRC Press; 1990:109-126.

21. Barrett F, Ranum P. Wheat and blended foods. In: Clydesdale FM, Wiemer KL, eds. Iron Fortification of Food. Orlando: Academic Press; 1985:75-109.

22. Hurrell RF, Furniss DE, Burri J, Whittaker P, Lynch SR, Cook JD. Iron fortification of infant cereals: a proposal for the use of ferrous fumarate or ferrous succinate. Am J Clin Nutr 1989;49:1274-1282.

23. Anderson R. Breakfast cereals and dry milled corn products. In: Clydesdale FM, Wiemer KL, eds. Iron Fortification of Foods. Orlando: Academic Press; 1985:75-109.

24. Fomon J. Bioavailability of supplemental iron in commercially prepared dry infant cereals. J Pediatr 1987;110:660-661.

25. Steinkamp R, Dubach R, Moore CV. Studies on the iron transportation and metabolism. VIII. Absorption of radioiron from iron-enriched bread. Arch Intern Med 1955;95:181.

26. Callender ST, Warner GT. Iron absorption from bread. Am J Clin Nutr 1968;21:1170-1174.

27. Cook JD, Minnich V, Moore CV, Rasmussen A, Bradley WB, Finch CA. Absorption of fortification iron in bread. Am J Clin Nutr 1973;26:861-872.

28. Hallberg L, Brune M, Rossander L. Low availability of carbonyl iron in man: studies on iron fortification of wheat flour. Am J Clin Nutr 1986;43:59-67.

29. Harrill IK, Hoene AE, Johnston FA. Iron absorbed from three preparations used to enrich bread. $J \mathrm{Am}$ Diet Assoc 1957;33:1010-1014.

30. Elwood PC. A clinical trial of iron fortified bread. BMJ 1963;1:224 -227.

31. Björn-Rasmussen E, Hallberg L, Rossander L. Absorption of fortification iron. Bioavailability in man of different samples of reduced iron, and prediction of the effects of iron fortification. Br J Nutr 1977;37: 375-388.

32. Fritz JC, Pla GW, Harrison BN, Clark GA. Estimation of the bioavailability of iron. J Assoc Off Anal Chem 1975;58:902-905.

33. Shah BG, Giroux A, Belonje B. Specification for reduced iron as food additive. J Agric Food Chem 1977;253:592-594.

34. Patrick J. Types of iron fortificants. Elemental sources. In: Clydesdale FM, Wiemer KL, eds. Iron Fortification of Foods. Orlando: Academic Press; 1985:31-38.

35. Hurrell RF. Fortification: overcoming technical and practical barriers. J Nutr 2002;132:806S-812S.

36. Handbook of Powder Metal Technologies and Applications. Volume 7. Materials Park, Ohio: American Society of Metals; 1998.

37. Food Chemicals Codex. Washington DC: National Academy Press; 1981.

38. Pla GW, Fritz JC. Availability of iron. J Assoc Off Anal Chem 1970;53:791-800.

39. Motzok I, Verma RS, Chen SS, Rasper J, Hancock RGV, Ross HU. Bioavailability, in vitro solubility, and physical and chemical properties of elemental iron powders. J Assoc Off Anal Chem 1978;61:887-893.

40. Forbes AL, Adams CE, Arnaud MJ, et al. Comparison of in vitro, animal and clinical determinations of iron bioavailability: International Nutritional Anemia Consultative Group Task Force report on iron bioavailability. Am J Clin Nutr 1989;49:225-238.

41. Whittaker $P$, Spivey Fox MR, Forbes AR. In vitro prediction of iron bioavailability for food fortification. Nutr Rep Int 1990;39:1205-1215.

42. Pla GW, Fritz JC. Collaborative study of the hemoglobin repletion test in chicks and rats for measuring availability of iron. J Assoc Off Anal Chem 1971;54: 13-17.

43. Ranhotra GS, Hepburn FN, Bradley WB. Availability of iron in enriched bread. J Assoc Off Anal Chem 1971;48:377-384.

44. Pla GW, Harrison BN, Fritz JC. Comparison of chicks and rats as test animals for studying the bioavailability of iron, with special reference to use of reduced iron in enriched bread. J Assoc Off Anal Chem 1973;56:1369-1373.

45. Pennell MD, Wiens WD, Rasper J, Motzo KI, Ross $\mathrm{HU}$. Factors affecting the relative biological value of food grade elemental iron powders for rats and humans. J Food Sci 1975;40:879-883.

46. Coccodrilli GD, Reussner GH, Theissen R. Relative biological value of iron supplements in processed food products. J Agric Food Chem 1976;24:351353.

47. Sacks PV, Houchin DN. Comparative bioavailability of elemental iron powders for repair of iron deficiency anemia in rats: studies of efficacy and toxicity of carbonyl iron. Am J Clin Nutr 1978;31:566571.

48. Shah BG, Belonje B. Rat bioassay of hydrogenreduced iron powder in flour and bread. Nutr Rep Int 1985;32:1171-1178.

49. Romanik EM, Miller DO. Iron bioavailability to rats from iron fortified infant cereals: a comparison of oatmeal and rice cereals. Nutr Rev 1986;34:591603.

50. Walter T, Dallman PR, Pizarro F, et al. Effectiveness of iron-fortified cereal in prevention of iron deficiency anaemia. Pediatrics 1993;91:976-982. 
51. Ranhotra GS, Loewe RJ, Puyst LV. Availability of iron in enriched soda crackers. J Assoc Off Anal Chem 1973;50:745-749.

52. Ranhotra GS, Lee C, Gelroth JA. Bioavailability of iron in some commercial variety breads. Nutr Rep Int 1979;19:851-857.

53. Kosonen T, Mutanen M. Relative bioavailability of iron in carbonyl iron and complex ferric orthophosphate to rat. Int J Vitam Nutr Res 1992;62:60-65.

54. Fritz JC. Bioavailability of mineral nutrients. Chemtech 1976;6:643-648.

55. Höglund S, Reizenstein P. Studies on iron absorption. 5. Effect of gastrointestinal factors on the iron absorption. Blood 1969;34:496.

56. Roe MA, Fairweather-Tait SJ. High bioavailability of reduced iron added to UK flour. Lancet 1999;353: 1938-1939.

57. Fairweather-Tait S, Fox TE, Wharf G, Eagles J. The bioavailability of different weaning foods and the enhancing effect of a fruit drink containing ascorbic acid. Pediatr Res 1995;37:389 -394.

58. Davidsson L, Galan P, Cherouvrier F, et al. Iron bioavailability from infant cereals by infants: the effect of dephytinization. Am J Clin Nutr 1997;65: 916-920.

59. Fox TE, Eagles J, Fairweather-Tait S. Bioavailability of iron glycine as a fortificant in infant foods. $A m \mathrm{~J}$ Clin Nutr 1998;67:664-668.

60. Hurrell RF, Reddy MB, Cook JD. Inhibition of non-haem iron absorption in man by polyphenolcontaining beverages. Br J Nutr 1999;81:289295.

61. Hurrell RF, Reddy MB, Burri J, Cook J D. An eval- uation of EDTA compounds for iron fortification of cereal-based foods. Br J Nutr 2000;84:903-910.

62. Hallberg L, Rossander L, Skanberg A-B. Phytates and the inhibitory effect of bran on iron absorption in man. Am J Clin Nutr 1987;45:988-996.

63. Hurrell RF, Juillerat MA, Reddy MB, Lynch SR, Dassenko SA, Cook JD. Soy protein, phytate and iron absorption in man. Am J Clin Nutr 1992;56: 573-578.

64. Elwood PC, Waters WE, Sweetran P. The haematinic effect of iron in flour. Clin Sci 1971;40:31-37.

65. Stekel A. Iron requirements in infancy and childhood. In: Stekel A, ed. Iron Nutrition in Infancy and Childhood. Nestlé Nutrition Workshop Series No 4. New York: Raven Press; 1984:1-10.

66. Stolzfus RJ, Dreyfuss ML, Chwaya HM, Albonico M. Hookworm control as a strategy to prevent iron deficiency. Nutr Rev 1997;55:223-232.

67. Hercberg S, Galan P, Dupin H. Iron deficiency in Africa. World Rev Nutr Diet 1987;54:201-236.

68. Suharno D, West CE, Muhcial Karyadi D, Hautrast JG. Supplementation with vitamin A and iron for nutritional anaemias in pregnant women in West Java. Lancet 1993;342:1325-1328.

69. van den Broek N, White SA, Nielson JP. The relationship between asymptomatic human immunodeficiency virus infection and the prevalence and severity of anemia in pregnant Malawian women. $A m \mathrm{~J}$ Trop Med Hyg 1998;59:1004-1007.

70. van den Broek N. Anaemia in pregnancy in developing countries. Br J Obstet Gynaecol 1998;105: 385-90.

\section{Erratum}

In the November 2002 issue of Nutrition Reviews, the issue number was erroneously printed as No. 12. The correct issue number is No. 11. 